\title{
PENGARUH PENDIDIKAN KESEHATAN TENTANG HIPERTENSI TERHADAP TINGKAT KECEMASAN PADA PENDERTTA HIPERTENSI DI KABUPATEN MAGELANG
}

\author{
Galih Adi Yuwono1, Moh Ridwan², Moh Hanafi ${ }^{3}$ \\ 1Mahasiswa Prodi D IV Keperawatan Magelang Poltekkes Kemenkes Semarang \\ 2,3Dosen Prodi Keperawatan Magelang Poltekkes Kemenkes Semarang \\ Email : galihadiyuwono21@gmail.com
}

\begin{abstract}
Hypertension is high blood pressure where pressure $\geq 140 \mathrm{mmHg}$ systolic and $\geq 90 \mathrm{mmHg}$ diastolic According to WHO (World Health Organization) in 2014 there were approximately 600 million people with hypertension in all around the world. When according Magelang District Health Office in 2013 as many as 10012 cases. To know the influence of health education about hypertension to anxiety level hypertension patient in Kwancen, Bandongan, Magelang. This research method is pre experimental with one group prepost-test research design. Sampling technique be used purposive sampling and total sample 35 respondents. Results : There is influence of health education to the level of anxiety in hypertension patient. There is a decrease in the level of anxiety in people with hypertension after getting health education.
\end{abstract}

Keywords : Health education, the level of anxiety, Hypertension.

\section{ABSTRAK}

Hipertensi merupakan tekanan darah tinggi dimana tekanan sistolik $\geq 140 \mathrm{mmHg}$ dan diastolik $\geq 90 \mathrm{mmHg}$. Menurut WHO (World Health Organization) tahun 2014 terdapat sekitar 600 juta penderita hipertensi di seluruh dunia. Sedangkan menurut Dinas Kesehatan Kabupaten Magelang tahun 2013 sebanyak 10.012 kasus. Mengetahui pengaruh pendidikan kesehatan tentang hipertensi terhadap tingkat kecemasan pada penderita hipertensi di Dusun Kwancen Desa Bandongan Kecamatan Bandongan Kabupaten Magelang. Metode penelitian ini adalah pre eksperimental dengan desain penelitian one group prepost-test. Teknik sampling yang digunakan yaitu purposive sampling dan jumlah sampel 35 responden. Terdapat pengaruh pemberian pendidikan kesehatan terhadap tingkat kecemasan pada penderita hipertensi. Adanya penurunan tingkat kecemasan pada penderita hipertensi setelah mendapatkan pendidikan kesehatan.

Kata Kunci : Pendidikan kesehatan, tingkat kecemasan, hipertensi. 


\section{PENDAHULUAN}

Belakangan ini banyak masalah kesehatan yang terjadi di masyarakat, mulai dari penyakit menular sampai penyakit tidak menular. Salah satu penyakit tidak menular dan merupakan faktor risiko utama dari stroke, infark miokard dan penyakit ginjal kronik adalah hipertensi, dimana tekanan darah sistolik $\geq 140 \mathrm{mmHg}$ dan diastolik $\geq 90 \mathrm{mmHg}$. Hal tersebut diakibatkan karena adanya perubahan gaya hidup dan rendahnya tingkat pengetahuan seseorang tentang kesehatan (Arifin, 2016).

Berdasarkan data menurut WHO (World Health Organization) pada tahun 2014 terdapat sekitar 600 juta penderita hipertensi di seluruh dunia. Prevalensi tertinggi terjadi di wilayah afrika yaitu sebesar $30 \%$ dan kejadian terendah terdapat di wilayah Amerika sebesar 18\%.

RISKESDAS pada tahun 2013 mencatat prevalensi di Indonesia sebesar $25,8 \%$, dengan angka kejadian tertinggi terdapat di Bangka Belitung 30,9\%, diikuti Kalimantan Selatan 30,8\%, Kalimantan Timur 29,6\% dan Jawa Barat 29,4\% (Arifin, 2016: 2). Di Jawa Tengah kasus hipertensi tertinggi tahun 2012 sebanyak 1,67\% (Dinkes Prov. Jateng, 2013).

Sedangkan menurut Dinas

Kesehatan Kabupaten Magelang pada tahun 2013 sebanyak 10.012 kasus, di Dusun Kwancen Desa Bandongan Kecamatan Bandongan kabupaten Magelang tahun 2016 terdapat 41 orang yang menderita hipertensi.

Kekhawatiran seseorang akan timbulnya suatu masalah-masalah baru yang ada pada hipertensi akan menyebabkan gangguan mental emosional atau perasaan yang sering kita jumpai salah satunya adalah kecemasan. Perasan itu muncul akibat ketakutan dan ketidaktahuan seseorang tentang apa yang di alaminya dan apa yang akan terjadi selanjutnya (Istirokah, 2013).

Berdasarkan studi pendahuluan yang peneliti lakukan kepada 5 orang penderita hipertensi yang di berikan kuisioner HARS (Hamilton Anxiety Rating Scale) terdapat 3 orang dengan cemas sedang dan 2 orang dengan cemas berat. Seseorang menganggap bahwa hipertensi adalah masalah yang serius dan selalu menyebabkan kecemasan karena ketidaktahuan seseorang tentang penyakit hipertensi seperti faktor penyebab, komplikasi dan cara pengobatan serta pencegahannya. Sangat diharapkan adanya penyuluhan kesehatan tentang hipertensi supaya penderita bisa mengontrol dirinya dari penyakit tersebut, sehingga bisa mengurangi tingkat kecemasan yang dirasakan.

Alasan penelitian ini mengambil di Desa Bandongan adalah karena masih jarang masyarakat desa yang mendapatkan pendidikan kesehatan serta masyarakat yang banyak berpartisipasi aktif dalam bidang kesehatan. Di Dusun Kwancen sendiri termasuk dusun yang paling banyak penderita hipertensi yang ada di Desa Bandongan.

\section{METODE}

Metode penelitian ini adalah pre eksperimental dengan desain penelitian one group prepost-test, yang mana penelitian ini tanpa kelompok kontrol, dilakukan pengukuran sebelum dan sesudah diberikan perlakuan. Penelitian ini dilakukan di Dusun Kwancen Desa Bandongan Kecamatan Bandongan Kabupaten Magelang pada tanggal 09 Januari - 20 Februari 2017. Populasi pada penelitian ini adalah penderita hipertensi yang ada di Dusun Kwancen Desa Bandongan Kecamatan Bandongan Kabupaten Magelang Tahun 2017. Jumlah sampel sebesar 37 responden, akan tetapi 
2 orang tidak memenuhi kriteria inklusi sehingga sampel yang diteliti adalah 35 responden. Teknik sampling yang digunakan pada penelitian ini yaitu non probability sampling dengan menggunakan pendekatan purposive sampling yaitu sampel yang dipilih oleh peneliti melalui penetapan berdasarkan kriteria tertentu. Teknik ini digunakan untuk mempermudah peneliti dalam pengambilan sempel (Sujarweni, 2014). Analisa data bivariat ini digunakan untuk mengetahui pengaruh pendidikan kesehatan tentang hipertensi terhadap tingkat kecemasan pada penderita hipertensi dengan alat bantu komputer, dengan menggunakan komperatif numerik berpasangan. Pertama uji normalitas, jika responden kurang dari 50 maka di uji menggunakan Shapiro-wilk, jika responden lebih dari 50 maka di uji menggunakan Kolmogorof. Untuk membandingkan sebelum dan sesudah perlakuan, apabila data berdistribusi normal $p$ value $>0.05$ maka menggunakan uji dependen $t$ test, sedangkan data berdistribusi tidak normal $p$ value $<0.05$ maka menggunakan uji wilcoxon.

\section{HASIL PENELITIAN}

1. Karakteristik Responden menurut Umur

\begin{tabular}{|c|c|c|}
\hline Umur & Frekuensi & Persentase $(\%$ \\
\hline $36-45$ & 2 & 5,7 \\
\hline $46-55$ & 6 & 17,1 \\
\hline $56-65$ & 17 & 48,6 \\
\hline$\geq 66$ & 10 & 28,6 \\
\hline Total (n) & 35 & 100,0 \\
\hline
\end{tabular}

Tabel 1 menggambarkan distribusi frekuensi responden berdasarkan umur. Karakteristik responden terbanyak adalah 56-65 tahun yaitu sebanyak 17 orang $(48,6 \%),>66$ tahun 10 orang $(28,6 \%)$, $46-55$ tahun 6 orang $(17,1 \%)$, sedangkan distribusi frekuensi terkecil adalah 36-45 tahun 2 orang (5,7\%).

2. Karakteristik Responden Hipertensi menurut Jenis Kelamin

Tabel 2. Distribusi Frekuensi Responden menurut Jenis Kelamin

\begin{tabular}{lcc}
\hline Jenis & Frekuensi & Persentase (\%) \\
Kelamin & 15 & 42,9 \\
\hline laki-laki & 20 & 57,1 \\
Perempuan & 35 & 100,0 \\
\hline Total $(\mathrm{n})$ & \\
\hline
\end{tabular}

Tabel 2 menggambarkan distribusi frekuensi responden menurut jenis kelamin di dapatkan jumlah responden perempuan lebih banyak dari laki-laki. Responden perempuan berjumlah 20 orang $(57,1 \%)$, sedangkan laki-laki 15 orang (42,9\%).

3. Karakteristik Responden Hipertensi menurut Pendidikan

Tabel 3. Distribusi Frekuensi

Responden menurut Pendidikan

\begin{tabular}{lcc}
\hline Pendidikan & Frekuensi & Persentase (\%) \\
\hline SD & 23 & 65,7 \\
SMP & 4 & 11,4 \\
SMA & 6 & 17,1 \\
PT & 2 & 5,7 \\
\hline Total $(\mathrm{n})$ & 35 & 100,0 \\
\hline
\end{tabular}

Tabel 3 menggambarkan bahwa distribusi frekuensi responden menurut pendidikan paling banyak yaitu SD dengan jumlah 23 orang $(65,7 \%)$, SMP 4 orang $(11,4 \%)$, SMA 6 orang $(17,1 \%)$, dan paling sedikit adalah perguruan tinggi yang hanya 2 orang $(5,7 \%)$. Dapat disimpulkan 
bahwa tingkat pendidikan dan pengetahuan responden rata-rata masih sangat rendah.

4. Karakteristik Responden Hipertensi menurut Pekerjaan]

Tabel 4. Distribusi Frekuensi Responden menurut Pekerjaan

\begin{tabular}{lcc}
\hline Pekerjaan & Frekuensi & Persentase (\%) \\
\hline PNS & 1 & 2.9 \\
Pegawai swasta & 3 & 8.6 \\
Wiraswasta & 1 & 2.9 \\
Petani & 8 & 22.9 \\
Pensiun & 4 & 11.4 \\
Pedagang & 4 & 11.4 \\
IRT & 11 & 31.4 \\
Buruh & 3 & 8.6 \\
\hline Total $(\mathrm{n})$ & 35 & 100.0 \\
\hline
\end{tabular}

Tabel 4 diatas menggambarkan hasil dari distribusi frekuensi responden menurut pekerjaan bahwa sebagian besar responden berkerja sebagai ibu rumah tangga yaitu berjumlah 11 orang $(31,4 \%)$, petani 8 orang $(22,9 \%)$, pedagang 4 orang $(11,4 \%)$, yang sudah pensiun ada 4 orang $(11,4 \%)$, buruh 3 orang $(8,6 \%)$, pegawai swasta 3 orang $(8,6 \%)$, PNS 1 orang $(2,9 \%)$, dan wiraswasta 1 orang $(2,9 \%)$.

5. Karakteristik Responden Hipertensi menurut Tekanan darah

Tabel 5. Distribusi Frekuensi Responden menurut Tekanan Darah Sebelum dan Sesudah Diberikan Intervensi

\begin{tabular}{ccccc}
\hline Variabel & \multicolumn{2}{c}{$\begin{array}{c}\text { Tekanan darah } \\
\text { sebelum perlakuan }\end{array}$} & \multicolumn{2}{c}{$\begin{array}{c}\text { Tekanan darah } \\
\text { setelah perlakuan }\end{array}$} \\
\cline { 2 - 5 } & Sistol & Diastol & sistol & Diastol \\
\hline $\begin{array}{c}\text { Terenda } \\
\text { h }\end{array}$ & 150 & 80 & 140 & 80 \\
$\begin{array}{c}\text { Tertinggi } \\
\text { Rata-rata }\end{array}$ & 180 & 110 & 180 & 100 \\
\hline
\end{tabular}

Tabel 5 menggambarkan distribusi frekuensi responden dan hasil yang didapatkan bahwa tekanan darah sebelum intervensi sistol paling rendah adalah $150 \mathrm{mmHg}$ dan diastol $80 \mathrm{mmHg}$. Sedangkan sistol tertinggi $180 \mathrm{mmHg}$ dan diastol $110 \mathrm{mmHg}$, rata-ratanya sistol $160 \mathrm{mmHg}$ dan diastol $95 \mathrm{mmHg}$. Setelah diberikan intervensi sistol paling rendah 140 $\mathrm{mmHg}$ dan diastol $80 \mathrm{mmHg}$. Sedangkan sistol tertinggi $180 \mathrm{mmHg}$ dan diastol $100 \mathrm{mmHg}$. Didapatkan rata-rata sistol setelah diberikan intervensi adalah $155 \mathrm{mmHg}$ dan diastol $92 \mathrm{mmHg}$. Terdapat pengaruh pada tekanan darah sebelum dan sesudah diberikan intervensi berupa pendidikan kesehatan.

6. Karakteristik Responden Hipertensi menurut Tingkat Kecemasan

Tabel 6. Distribusi Frekuensi

Responden menurut Tingkat

Kecemasan Sebelum dan Sesudah Diberikan Intervensi

\begin{tabular}{lcccc}
\hline Variabel & \multicolumn{2}{c}{$\begin{array}{c}\text { Pre Test } \\
\text { Tingkat } \\
\text { Kecemasan }\end{array}$} & \multicolumn{2}{c}{$\begin{array}{c}\text { Post Test } \\
\text { Tingkat } \\
\text { Kecemasan }\end{array}$} \\
\cline { 2 - 5 } & $\mathrm{n}$ & $\%$ & $\mathrm{n}$ & $\%$ \\
\hline Tidak & 0 & 0 & 19 & 54,3 \\
Cemas & & & & \\
$\begin{array}{l}\text { Cemas } \\
\text { Ringan }\end{array}$ & 25 & 71,4 & 13 & 37,1 \\
$\begin{array}{l}\text { Cemas } \\
\text { Sedang }\end{array}$ & 10 & 28,6 & 3 & 8,6 \\
\hline Total(n) & 35 & 100 & 35 & 100 \\
\hline
\end{tabular}

Tabel 6 menggambarkan distribusi frekuensi responden menurut tingkat kecemasan. Sebelum diberikan intervensi, responden mengalami kecemasan ringan dengan jumlah 25 orang $(71,4 \%)$ dan cemas sedang 10 orang $(28,6 \%)$. Setelah diberikan intervensi, responden yang tidak mengalami cemas sebanyak 19 
orang $(54,3 \%)$, cemas ringan 13 orang $(37,1 \%)$, dan cemas sedang 3 orang $(8,6 \%)$. Dapat disimpulkan bahwa ada pengaruh yaitu penurunan tingkat kecemasan setelah diberikan intervensi berupa pendidikan kesehatan.

7. Karakteristik menurut Skor Kecemasan Sebelum dan Sesudah Intervensi

Tabel 7. Ditribusi Frekuensi Responden Menurut Skor Kecemasan Sebelum dan Sesudah Intervensi

\begin{tabular}{cccc}
\hline Variabel & Mean & Min-Mak & SD \\
\hline $\begin{array}{c}\text { Skor } \\
\text { Kecemasan } \\
\text { sebelum }\end{array}$ & 13,43 & $8-24$ & 4,71 \\
intervensi & & & \\
$\quad$ Skor & 7,69 & $3-18$ & 4,15 \\
Kecemasan & & & \\
sesudah \\
intervensi
\end{tabular}

Tabel 7 menggambarkan distribusi frekuensi responden menurut skor kecemasan sebelum dan setelah diberikan intervensi. Hasil yang didapatkan bahwa skor kecemasan dengan rata-rata sebelum intervensi 13,43 menjadi 7,69 . Nilai minimal dari 8 turun ke skor 3 , sedangkan nilai maksimum 24 menjadi 18. Standar deviation 4,71 menjadi 4,15 dengan IK 95\% dari 11,81-15,05 menjadi 6,25-9,11.

8. Uji Normalitas Data

Tabel 8. Hasil Uji Normalitas Data Menggunakan Shapiro-Wilk

\begin{tabular}{cccc}
\hline Variabel & \multicolumn{3}{c}{ Shapiro-Wilk } \\
\cline { 2 - 4 } & Statistic & df & Sig. \\
\hline $\begin{array}{c}\text { Skor Kecemasan } \\
\text { sebelum intervensi } \\
\begin{array}{c}\text { Skor Kecemasan } \\
\text { sesudah intervensi }\end{array}\end{array}$ & .882 & 35 & .001 \\
\hline
\end{tabular}

Tabel 8 menggambarkan uji normalitas menggunakan Shapiro-wilk karena responden $<50$ dan dikatakan normal apabila nilai $p>0,05$ dan data dikatakan tidak normal apabila $p$ $<0,05$. Dari data diatas dapat dilihat bahwa hasil uji normalitas $p=0.001$ untuk skor kecemasan sebelum dilakukan intervensi dan $p=0,000$ untuk skor kecemasan setelah dilakukan intervensi. Maka dapat diartikan bahwa data diatas tidak normal, sehingga uji hipotesis menggunakan uji Wilcoxon.

9. Analisis Uji Statistik (Wilcoxon)

Tabel 9. Analisis Pengaruh Pendidikan Kesehatan Tentang Hipertensi Terhadap Tingkat Kecemasan Pada Penderita Hipertensi di Dusun Kwancen Desa Bandongan Kecamatan Bandongan Kabupaten Magelang

\begin{tabular}{ccc}
\hline Variabel & $\begin{array}{c}\text { Median } \\
(\text { Min-Max) }\end{array}$ & Nilai p \\
\hline $\begin{array}{c}\text { Tingkat kecemasan } \\
\text { sebelum intervensi }\end{array}$ & $12(8-24)$ & \\
$\begin{array}{c}\text { Tingkat kecemasan } \\
\text { setelah intervensi }\end{array}$ & $6(3-18)$ & 0,000 \\
\hline
\end{tabular}

Tabel 4.9 menggambarkan hasil dari uji statistik Wilcoxon pada peneilitian ini yaitu $p=0,000$, dimana data dikatakan memiliki pengaruh apabila nilai $p<0,05$. Dari data diatas, maka $\mathrm{HO}$ ditolak dan $\mathrm{H} 1$ diterima, artinya ada pengaruh terhadap tingkat kecemasan pada penderita hipertensi sebelum dan setelah diberikan pendidikan kesehatan di Dusun Kwancen Desa Bandongan Kecamatan Bandongan Kabupaten Magelang.

\section{PEMBAHASAN}

1. Karakteristik Responden 
Hasil analisis menurut umur responden hipertensi terhadap 35 orang didapatkan frekuensi paling banyak antara 56-65 tahun dengan proporsi 17 orang $(44,6 \%)$. Hal ini menunjukkan bahwa banyak yang sudah memasuki masa lansia akhir, dan $>66$ tahun atau sudah manula 10 orang $(28,6 \%)$, selebihnya $36-55$ tahun sebanyak 8 orang. Dapat disimpulkan bahwa usia tua lebih rentan terkena penyakit hipertensi dibandingkan dengan usia muda. Karena seiring bertambahnya usia maka fungsi-fungsi tubuh akan mengalami penurunan dan mengakibatkan para lansia jatuh dalam kondisi sakit, hal ini disebut dengan proses degeneratif. Salah satu proses yang terjadi adalah pada sistem kardiovaskular seperti yang sering kita jumpai salah satunya adalah hipertensi, dimana elastisitas pembuluh darah kita berkurang sehingga cenderung mengalami penyempitan dan menyebabkan peningkatan tekanan darah (Salafudin, 2015).

Hal ini berarti semakin tua umur seseorang maka akan semakin menurun pula semua keadaan fisiknya, sistem imun yang melemah dan kurangnya respon tubuh dalam mencegah penyakit. Sehingga jika tidak berhati-hati dalam melakukan aktifitas, mengkonsumsi makanan, manjaga pikiran dan memperhatikan kondisi tubuh serta kesehatan maka akan mudah terkena penyakit seperti hipertensi yg banyak di temukan pada lansia.

Hasil analisis yang diperoleh bahwa responden yang mengalami hipertensi didominasi oleh perempuan sebanyak 20 orang $(57,1 \%)$, dan laki- laki 15 orang $(42,9 \%)$ dari 35 responden.

Tekanan darah cenderung meningkat pada perempuan setelah menopause, hal ini disebabkan oleh faktor psikologi dan adanya perubahan dalam diri wanita tersebut seperti perubahan hormon estrogen dan progesteron. Hampir 50\% penderita hipertensi adalah perempuan, karena mereka memiliki beberapa kondisi khusus yang berhubungan dengan asupan kalsium, masa kehamilan, kontrasepsi oral, dan menopause (Susi, 2014). Jenis kelamin perempuan pada penelitian ini lebih banyak mengalami hipertensi dibandingkan laki-laki, dikarenakan mereka masih sulit dalam mengontrol kesehatannya. Apalagi banyak didapatkan yang sudah mengalami menopause. Selain sistem tubuh dan hormon yang menurun, stress karena keadaan dan lingkungan juga sangat mempengaruhinya.

Berdasarkan pendidikan, mayoritas responden adalah lulusan SD sebanyak 23 orang $(65,7 \%)$, SMP 4 orang $(11,4 \%)$, SMA 6 orang $(17,1 \%)$, dan perguruan tinggi hanya 2 orang $(5,7 \%)$. Artinya sebagian besar responden berada dalam tingkat pengetahuan sangat rendah yang hanya lulusan sekolah dasar, dikarenakan keterbatasan masyarakat sekitar dalam masalah ekonomi yang sangat berpengaruh terhadap kesehatan. Semakin tinggi tingkat pendidikan maka akan semakin baik pengetahuannya. Seseorang yang mengalami hipertensi dengan tingkat pendidikan yang sangat rendah disebabkan karena kurangnya pengetahuan tentang kesehatan maupun penyakit yang dialaminya 
sehingga sulit untuk mengontrol masalah kesehatannya (Susanti, 2013).

Tingkat pendidikan yang rendah pada responden yang didapatkan sangat berpengaruh besar terhadap hipertensi yang dideritanya, karena kurangnya wawasan tentang kesehatan menyebabkan cara berfikir yang kurang efektif dalam menanggapi dan menjaga berhubungan dengan masalahmasalah kesehatannya.

Hasil analisis responden menurut pekerjaan sebagian besar berkerja sebagai ibu rumah tangga dengan jumlah 11 orang $(31,4 \%)$, petani 8 orang $(22,9 \%)$, pedagang 4 orang $(11,4 \%)$, yang sudah pensiun ada 4 orang $(11,4 \%)$, buruh 3 orang $(8,6 \%)$, pegawai swasta 3 orang $(8,6 \%)$, PNS 1 orang $(2,9 \%)$, dan wiraswasta 1 orang $(2,9 \%)$.

Dalan penelitian yang dilakukan Sutangi (2013) dikatakan bahwa hampir semua orang mengalami stress dengan pekerjaan mereka karena dipengaruhi dengan tuntutan kerja yang terlalu banyak dan memerlukan tanggung jawab yang sangat besar atas pekerjaanya sehingga merasa pikirannya terbebani dan memicu terjadinya tekanan darah tinggi. Ibu rumah tangga setiap harinya hanya mengurusi persoalan dirumah banyak yang di pikirkan dan menyebabkan kecemasan serta stress yang tinggi dibandingakan dengan ibu yang berkerja (Udjianti, 2010).

Pekerjaan dapat mempengaruhi hipertensi karena dalam melakukan kerja banyak beban yang dirasakan kemudian menyebabkan seseorang seringkali stress dan cemas dalam memikirkan hal tersebut yang memicu tekanan darah tinggi.

2. Tekanan Darah pada Responden Sebelum dan Sesudah Diberikan Pendidikan Kesehatan di Dusun Kwancen Desa Bandongan Kecamatan Bandongan Kabupaten Magelang

Hasil penelitian menunjukkan bahwa tekanan darah sebelum dan sesudah dilakukan intervensi mengalami perubahan. tekanan sistol sebelum intervensi paling rendah adalah $150 \mathrm{mmHg}$ dan diastol paling rendah $80 \mathrm{mmHg}$. Sedangkan sistol paling tinggi $180 \mathrm{mmHg}$ dan diastol paling tinggi $110 \mathrm{mmHg}$, rata-ratanya sistol $160 \mathrm{mmHg}$ dan diastol 95 $\mathrm{mmHg}$. Setelah diberikan intervensi sistol paling rendah $140 \mathrm{mmHg}$ dan diastol paling rendah $80 \mathrm{mmHg}$. Sedangkan sistol paling tinggi 180 $\mathrm{mmHg}$ dan diastol paling tinggi 100 $\mathrm{mmHg}$. Didapatkan rata-rata sistol setelah diberikan intervensi adalah $155 \mathrm{mmHg}$ dan diastol $92 \mathrm{mmHg}$.

Tekanan darah dipengaruhi oleh beberapa faktor seperti genetik, stress, cemas dan psikologis, lingkungan, gaya hidup maupun komplikasi penyakit. Dalam bahasan ini menunjukkan bahwa pendidikan kesehatan mempengaruhi tekanan darah. Seseorang yang menderita hipertensi salah satunya mengalami kecemasan yang disebabkan kurangnya pengetahuan tentang penyakit yang dialaminya sehingga dapat meningkatkan tekanan darah. Akan tetapi dengan adanya pengetahuan melalui pendidikan kesehatan, tingkat kecemasan menjadi berkurang karena responden menjadi tau apa yang dialaminya dan cara mengontrolnya jada tidak perlu lagi ada yang di khawatirkan tentang 
penyakitnya. Sesuai dengan penelitian yang dilakukan oleh Kurniawan (2013).

Pendidikan kesehatan
memberikan wawasan baru,
mengurangi ketegangan dan
ketakutan pada seseorang yang
khawatir akan penyakitnya sehingga dapat menurunkan tekanan darah yang tadinya tinggi karena perasaan cemas dan khawatir terhadap hal yang serius terkait dengan penyakit yang dideritanya kemudian memicu hipertensi.

3. Tingkat Kecemasan pada Penderita Hipertensi Sebelum Dilakukan Pendidikan Kesehatan di Dusun Kwancen Desa Bandongan Kecamatan Bandongan Kabupaten Magelang 'Hasil analisis penelitian menunjukkan bahwa sebelum dilakukan pendidikan kesehatan pada umumnya responden mangalami kecemasan ringan dengan jumlah 25 orang $(71,4 \%)$ dan cemas sedang 10 orang $(28,6 \%)$. Setelah mengetahui penyakit yang dialaminya, seseorang cenderung khawatir dengan apa yang akan terjadi selanjutnya apabila tidak segera diatasi. Kecemasan bisa dilihat melalui kuesioner skala HARS (Hamilton Anxiety Rating Scale,) saat dilakukan penilaian rata-rata responden mengalami perasaan cemas, gelisah dan sesuatu yang buruk akan terjadi. Gejala yang muncul seperti sulit tidur mudah berkeringat, sering pusing dan muka tegang. Hal tersebut diakibatkan karena responden tidak menyadari tentang penyakitnya dan hanya bisa merasakan gejalanya. Seseorang mempersepsikan bahwa hipertensi adalah masalah paling serius di masyarakat yang sering terjadi yang menyebabkan stroke, serangan jantung bahkan kematian. Saat masalah itu muncul pada diri individu dan mereka mengetahuinya, seketika itu juga mereka terkejut sehingga perasaan cemas muncul karena dalam lingkungannya belum ada sosialisasi atau penyuluhan pada masyarakat tentang masalah kesehatan seperti hipertensi

Seperti penelitian yang dilakukan oleh Istirokah (2013) yang menyebutkan bahwa hipertensi merupakan penyakit tanpa gejala yang menyebabkan kematian secara tibatiba. Keadaan ini akan membuat khawatir pada para penderitanya sehingga tekanan darah akan cepat meningkat dan tanpa disadari gejalanya. Hasil teori ini ditemukan pada saat penelitian yang menunjukkan berbagai macam gejala kecemasan secara tiba-tiba setelah responden mengetahui bahwa dirinya menderita hipertensi. Ketakutan, kecemasan, dan kekhawatiran adalah perasaan yang muncul yang diakibatkan seseorang tidak mengetahui secara pasti tentang penyakitnya dan cara penanganannya.

Setelah

seseorang mengetahui bahwa dirinya menderita hipertensi maka pada saat itu juga mengalami kecemasan dan berfikir yang lebih buruk terhadap penyakitnya karena menjadi beban yang sangat penting dalam masalah kesehatannya. Sebelum pendidikan kesehatan dilakukan, banyal hal yang dipikirkan terutama sesuatu keadaan buruk akan menimpanya sehingga kecemasan muncul akibat dari ketidaktahuan tentang penyakitnya dan cara untuk melawannya. 
4. Tingkat Kecemasan pada Penderita Hipertensi Setelah Dilakukan Pendidikan Kesehatan di Dusun Kwancen Desa Bandongan Kecamatan Bandongan Kabupaten Magelang

Berdasarkan hasil analisis penelitian yang didapatkan rata-rata responden setelah diberikan pendidikan kesehatan tentang hipertensi mengalami penurunan tingkat kecemasan, yang sudah tidak mengalami cemas berjumlah 19 orang $(54,3 \%)$, cemas ringan 13 orang $(37,1 \%)$, dan cemas sedang 3 orang $(8,6 \%)$.

Tingkat pengetahuan responden tentang kesehatan maupun penyakit yang dialaminya seperti masalah hipertensi sebelum dilakukan intervensi masih sangat kurang bahkan ada yang sama sekali belum mengetahuinya. Hal ini disebabkan karena belum adanya sosialisasi dari pihak yang berwenang ataupun akibat dari kurangnya keaktifan masyarakat dalam memperhatikan dan peduli terhadap dirinya sendiri terutama dalam menjaga kesehatan. Kecemasan yang dialami seseorang salah satunya dikarenakan kurangnya wawasan yang luas dan pengetahuan yang cukup. Seseorang cenderung lebih berfikir yang buruk terhadap sesuatu hal yang mengancam dirinya karena rasa takut dan khawatir yang muncul. Akan tetapi setelah mereka mengetahui cara mengontrol terhadap sesuatu hal yang mengancam dirinya, maka perasaan yang lebih rileks dan tenang memberikan cara berfikir yang lebih baik dalam mengatasi segala permasalahan tentang penyakit yang dialaminya (Lestari, 2014)

Seperti penelitian yang dilakukan oleh Kurniawan (2013) yang menjelaskan tentang cara mengatasi kecemasan pada seseorang dengan memberikan pendidikan kesehatan guna memenuhi serta meningkatkan kebutuhan dan pengetahuan tentang kesehatan maupun penyakit kepada masyarakat.

Setelah seseorang mendapatkan pendidikan kesehatan berkaitan dangan penyakitnya, kecemasan yang dialaminya akan menurun sebab tidak perlu lagi ada yang di takutkan dan dipikirkan dalam merasakan penyakitnya karena sudah tau cara mengontrol dan menjaganya supaya tidak terjadi komplikasi lebih lanjut dan bisa mengurangi tingkat penyakitnya.

5. Pengaruh Tingkat Kecemasan Sebelum dan Sesudah Mendapatkan Pendidikan Kesehatan di Dusun Kwancen Desa Bandongan Kecamatan Bandongan Kabupaten Magelang

Dari hasil uji hipotesis penelitian menggunakan uji statistik Wilcoxon diperoeh nilai $p=0,000$ dimana data dikatakan memiliki pengaruh apabila $p<0,05$ sehingga $\mathrm{H} 1$ diterima dan $\mathrm{HO}$ ditolak, yang artinya ada pengaruh yang signifikan dengan pemberian pendidikan kesehatan tentang hipertensi terhadap tingkat kecemasan pada penderita hipertensi di Dusun Kwancen Desa Bandongan Kecamatan Bandongan Kabupaten Magelang.

Menurut penelitian yang dilakukan oleh Istirokah (2013) didapatkan bahwa kekhawatiran seseorang akan timbulnya suatu masalah-masalah baru yang ada pada penyakit hipertensi akan menyebabkan gangguan mental emosional atau perasaan tidak menyenangkan pada penderitanya 
maupun orang yang baru saja terdiagnosa, seperti yang sering kita jumpai dan kita sendiri merasakannya salah satunya adalah kecemasan. Perasan ini muncul akibat dari dampak psikologis seseorang sejak mengetahui bahwa dirinya mengalami masalah pada kesehatannya dan merupakan suatu katakutan terhadap sesuatu yang tidak di ketahuinya.

Kecemasan merupakan respon terhadap suatu ancaman dan hal yang tidak diketahui dengan jelas penyebabnya, dan salah satu keadaan emosional seseorang dengan tingkat yang berbeda-beda. Keadaan tersebut bisa mengganggu kehidupan seseorang apabila sudah sampai ke tingkat yang sedang dan berat. Karena kurangnya pengetahuan dan wawasan tentang masalah yang dihadapinya terutama pada penyakit yang dideritanya seperti hipertensi (Hardy, 2012).

Penelitian dari Sari (2012) menjelaskan tentang hasil dari pemberian pendidikan kesehatan mampu mengurangi tingkat kecemasan dengan cukup baik. Dikarenakan hal itu mampu merubah pola pikir seseorang menjadi lebih paham dan mengerti tentang apa yang akan dilakukan selanjutnya serta mengontrol keadaan yang sesuai dengan apa yang dialaminya seperti masalah kesehatan dalam melawan penyakit.

Adapun penelitian lain yang menunjang pembahasan pada bab ini adalah dari Setyaningsih (2013) dengan melakukan penelitian terhadap tingkat kecemasan yang dipengaruhi oleh beberapa faktor dari masing-masing individu itu sendiri tergantung pada koping ysng dilakukan. Akan tetapi, tingkat pengetahuan juga menjadi masalah utama yang dapat menyebabkan kecemasan ringan bahkan berat. Pengetahuan yang rendah memicu seseorang untuk berfikir yang buruk tanpa mengetahui secara pasti apa yang terjadi pada dirinya tidak sesuai dengan apa yang ada dalam pikirannya. Salah satu cara mengatasinya dengan melakukan pendidikan kesehatan terhadap penderita, pihak keluarga maupun masyarakat sekitar dengan cara mendengar, memerintahkan, menyarankan, menjelaskan, mendiskusikan dan membantu memutuskan permasalahan yang ada tentang kesehatan supaya meraka bisa melakukan koping dengan baik untuk mengurangi kecemasan dan mengatasi penyakitnya.

Pendidikan kesehatan mempengaruhi tingkat kecemasan seseorang yang menderita hipertensi karena sebelum dilakukan pendidikan kesehatan, perasaan cemas muncul akibat dari penyakit dialaminya yang disebebkan karena kurangnya pengetahuan seseorang tentang hipertensi sehingga mereka khawatir dan berpikiran buruk tentang apa yang akan terjadi selanjutnya tanpa mengetahui cara mencegah, mengontrol dan menanganinya. Akan tetapi, setelah mendapatkan pendidikan kesehatan para penderita hipertensi menjadi lebih mengerti akan penyakitnya bagaimana mencegahnya dan mengobatinya supaya tidak terjadi komplikasi yang lebih lanjut dan halhal yang tidak diinginkan. Sehingga kecemasan yang dialaminya bisa menurun ke tingkat ynag lebih rendah bahkan merasa tidak cemas lagi. 


\section{KESIMPULAN}

Tingkat kecemasan responden sebelum diberikan pendidikan kesehatan tentang hipertensi didapatkan kecemasan ringan sebanyak 25 orang, dan kecemasan sedang 10 orang. Tingkat kecemasan responden setelah diberikan pendidikan kesehatan tentang hipertensi didapatkan jumlah yang tidak mengalami kecemasan adalah 19 orang, kecemasan ringan 13 orang, dan keccemasan sedang 3 orang. Ada perbedaan tingkat kecemasan bermakna sebelum dan setelah diberikan pendidikan kesehatan tentang hipertensi.

\section{DAFTAR PUSTAKA}

Arifin, M. H., Weta, I., \& Ratnawati. (2016). Faktor-Faktor yang Berhubungan dengan Kejadian Hipertensi pada Kelompok Lanjut Usia di Wilayah Kerja UPT Puskesmas Petang I Kabupaten Badung Tahun 2016, $5(7), 2$.

Dahlan, M. S. (2014). Statistik Untuk Kesehatan dan Kedokteran: Deskriptif, Bivariat, dan Multivariat. Jakarta.

Dinas Kesehatan. Profil Kesehatan Kota Magelang Tahun 2013. (2013).

Hardy, S., purnama, Anita, \& Theresia. (2012). Hubungan Tingkat Kecemasan Dengan Morbus Hansen dan Faktor - Faktor yang Mempengaruhinya di Bagian Kulit dan Kelamin BLU RSUP Prof. Dr. R. D. Kandou Manado Periode November - Desember 2012, 1-2.

Herlambang. (2013). Menaklukkan Hipertensi \& Diabetes: Mendeteksi, Mencegah dan Mengobati Dengan Cara Medis dan Herbal. Jakarta Selatan: Tugu Publisher.

Istirokah, I., Surtiningrum, A., \& Nurullita, U. (2013). Pengaruh Terapi Tertawa terhadap Penurunan Tingkat
Kecemasan pada Penderita Hipertensi (Studi di Wilayah Kerja Puskesmas Pegandan Semarang), 1-2.

Kurniawan, A., Armiyati, Y., \& Astuti, R. (2013). Pengaruh Pendidikan Kesehatan Pre Operasi terhadap Tingkat Kecemasan pada Pasien Pre Operasi Hernia di RSUD Kudus, 6(2), 2.

Lestari, T. (2015). Kumpulan Teori Untuk Kajian Pustaka Penelitian Kesehatan. Yogyakarta: Nuha Medika.

Maria, Susanti, Mega Tri, S. (2012). Pengaruh Pendidikan Kesehatan Tentang Hipertensi terhadap Pengetahuan dan Sikap Mengelola Hipertensi di Puskesmas Pandanaran Semarang. Karya IImiah S.1 IImu Keperawatan, (Tahun 2012). Retrieved from http://pmb.stikestelogorejo.ac.id/ejournal/index.php/ilmukeperawatan/a rticle/view/66

Monica, S., Keloko, A. B., \& Syahrial, E. (2015). Gambaran Karakteristik dan Sosial Budaya Masyarakat terhadap Kejadian Hipertensi di Wilayah Kerja Puskesmas Sawit Seberang Kecamatan Sawit Seberang Kabupaten Langkat 2015, 1-2.

Ruswanto, dkk. (2014). Profil Kesehatan Kabupaten Magelang 2014.

Salafudin, \& Handayani, S. (2015). Pengaruh Teknik Relaksasi Benson terhadap Tekanan Darah pada Lansia Penderita Hipertensi di Posyandu Lansia Larasati Dusun Wiyoro Baturetno Banguntapan Bantul Yogyakarta 2015, 6(2), 151.

Sari, N., dan Istichomah. (2012). Pengaruh Pendidikan Kesehatan Tentang Resiko Perilaku Kekerasan (RPK) terhadap Pengetahuan Keluarga Dalam Merawat Pasien di Poli Jiwa RSJD Dr. RM. Soedjarwadi Klaten 
Jawa Tengah, 6(1), 26.

Sedayu, B., Azmi, S., \& Rahmatini. (2013). Artikel Penelitian Karakteristik Pasien Hipertensi di Bangsal Rawat Inap SMF Penyakit Dalam RSUP DR . M . Djamil Padang Tahun 2013, 4(1), 66.

Setiati, S., Alwi, I., Sudoyo, A., Simadibrata, M., Setiyohadi, B., \& Syam, A. F. (2013). Ilmu Penyakit Dalam. Jakarta: Interna Publishing.

Setyaningsih, T., Meirina S. (2013). Perbedaan Tingkat Kecemasan Pre dan Post Operasi di Bangsal Bedah Kenanga RSUD Prof. Dr. Margono Soekarjo Periode 1-5 Oktober 2012, 6(1), 415.

Sujarweni, V. W. (2014). Metodologi Penelitian Keperawatan. Yogyakarta: Gava Media.

Susi, Hiswani, \& Jemadi. (2014). Faktor-
Faktor yang Berhubungan dengan Hipertensi pada Lansia Usia Pertengahan di Desa Belang Malum Kecamatan Sidikalang Kabupeten Dairi Tahun 2014, 2.

Sutangi, H., \& Winantri. (2011). Faktor yang Berhubungan dengan Kejadian Hipertensi pada Wanita Lansia di Posbindu Desa Sukaurip Kecamatan Balongan Indramayu, 1-8.

Swarjana, K. (2014). Metodelogi Penelitian Kesehatan (Edisi Revisi). Yogyakarta : CV Andi Offiset.

Widyanto, F. C. (2014). Keperawatan Komunitas dengan Pendekatan Praktis. Yogyakarta: Nuha Medika.

Wijaya, Andra Saferi \& Putri, Yessie Mariza. (2013). KMB 1 Keperawatan Medikal Bedah Teori dan Contoh Askep. Yogyakarta : Nuha Medika 